\title{
A IMPORTÂNCIA DA LITERATURA PARA O HOMEM DE CULTURA UNIVERSITÁRIA, QUALQUER QUE SEJA SUA ESPECIALIZAÇÃO (*).
}

A mensagem literária dirige-se hoje para um homem que vive numa época de especialização, que exige o culto às ciências naturais como o único digno de si.

Partindo dessa premissa, uma evidência se nos aponta: encontramos médicos, engenheiros e advogados, mas não o "homem" inserido nessas profissões. Essa especialização diferencia-os do resto da humanidade. Submergidos em suas atividades êstes não têm oportunidade para serem no meio dos homens, "iguais entre iguais".

A especialização é o signo de nossa época. O gigantesco desenvolvimento do conhecimento nas ciências naturais, a centralização de esforços dos Institutos Universitários em tôrno das pesquisas físicas longe de prescindirem de um sentido humano à sua atividade, colocam-no com mais dramaticidade.

E' o espantoso desenvolvimento das ciências naturais que revela o fato do homem achar-se num período de transição. Os velhos valores fenecem e os novos não foram ainda encontrados. Esse vácuo é preenchido pela incerteza do homem quanto ao seu destino (1).

(*). - Trabalho premiado - prêmio Graciliano Ramos - nn concurso de literatura para os universitários do país, instituído pelo Ministério de Educação e Cultura e pela revista o Cruzreiro, conforme sua publicação de 2-1-60.

(1). - A respeito da incerteza do homem/quanto ao seu destino individual, num mundo em mudança, existe uma vasta bibliografia, cujos pontos de vista mais relevantes aparecem expostos em:

S. Freud - Civilisation and its discontents. Londres, 1930.

J. Ortega y Gasset :- La rebelion de las massas. Madri, 1930.

Huizinga - Entre las sombras del mañana. Madrí, 1936.

Niebuhr - Moral and imoral society. A study in ethics and politics. Nova York, 1932.

Os trabalhos acima estão pautađos por uma visão romântica e pessimista ante os problemas da técnica numa socledade de massas e suas repercussōes morals, políticas e econômicas.

Uma posição mais construtiva e realista em relação aos mesmos fenômenos se encontrará em:

Karl Mannheim - Libertad y Planificacion Social. México, 1946.

Karen Horney - The neurotic personality of our time. Londres, 1937.

Erich Fromm - Psicanalise da sociedade contemporânea. São Paulo, 1959. 
Numa época de especialização (2), a literatura define os ideais de um período de crise e transição. Daí tôda grande obra literária ser de um período de transição (veja-se a importância da mensagem de Dante, Dostoievski ou Kafka) .

Pois é nesses períodos que se põe dramàticamente ao homem essa interrogação: qual o sentido de sua vida, qual a significação do mundo que o cerca?

O médico, engenheiro, advogado, encarnam especializações necessárias ao exercício de suas atividades, mas têm em comum, um atributo; o de serem humanos e o de enfrentarem idênticos problemas numa sociedade em transição.

Somos filhos de uma sociedade individualista e liberal e caminhamos para um outro tipo de sociedade planificada. Como dar-se-á tal mudança? Quais os agentes dêsse processo? Não o sabemos. O que sabemos é que assistimos a' um espetáculo de crise, de transição, onde os velhos quadros sociais desaparecem e os novos ainda não se estruturaram.

A literatura é uma forma de resposta a essa interrogação. Ela, pelos escritos de Homero transmitia-nos uma mensagem corporificando um tipo de homem: o cavaleiro e o nobre; pela pena de Hesíodo, transmitia-nos uma ética do trabalho e sua dignificação como sentido da vida (3). Os escritos de Joyce, Kafka e Faulkner, constituem uma mensagem adeqüada aos tempos novos: as formas clássicas do romance estão fenecendo; cabe ao homem descobrir uma nova linguagem para exprimir novas experiências de uma nova vida (4).

De tôdas as formas de arte a literatura é a mais próxima da vida e a mais sintética, pois reune a arquitetura, quando no

(2). - A respeito da tendência irrecorrível de nossa civilização jà especialização, veja-se Gerth e Mills - "From Max Weber", cap. Science as vocation. Londres, 1955.

(3): - Sôbre a importância da literatura como "formação do homem" em Homero e Hesíodo, veja-se; Werner Jaeger - Paidéia - I volume, (págs. 53-93. México, 1949 .

(4). - o "tipo ideal" de romance construído arquitetônicamente é o de Balzac. "La Commedie Humaine" representa o ideal linear do romance do século XIX. Com "Les Faux Monnayeurs" de A. Gide, êste esquema de desenvolvimento linear da ação do romance deixa lugar à simultaneidade das ações. Esta ruptura com a construção tradicional de romance é salientada por Claude Edmonde-Magny quando escreve: "en écrivant "Les Faux Monnayeurs", ce modèle de "sur-roman", Gide refuse la conception traditionelle du' genre, avec une vigueur, à peine moins grande, que celle de son ami Paul Ambroise" in "Histoire du roman français depuis de 1918 , pág. 229. Paris, 1950. Joyce representa uma nova experiência construtiva utilizando um tema clássico. Diferentemente dos modernos é introspectivo. o monólogo interior é a razão de Dédalo, é uma forma de existência. Joyce lançou essa técnica já descoberta anteriormente por um francês, Edouard Dejardin. Antes de Joyce, já o inglês Stephen Hudson dêle já fazia uso. Até o nosso semi-conhecido Adelino Magalhães já usava-o. 
processo de composição do romance, a música, na estrutura melódica da frase, a pintura, no traçar o caráter dos personagens, a filosofia, ao definir seus ideais de vida. Daí sua importância para a cultura.

Sendo ela acessível aos diferentes especialistas, poderá formular novas formas de ação ética e padrões morais. Como um sismógrafo poderá ela captar o sentido interno da mudança que se opera no mundo. Para tal, conta com a intuição artística, que faz com que as mudanças sejam pressentidas antes pelos seus possuidores, passando depois aos campos sistemáticos do conhecimento.

A transição do século XIX ao XX foi assinalada, em primeiro lugar, pelos impressionistas, pelo naturalismo literário e posteriormente pelos teóricos de política, economia e filosofia.

A literatura pertencendo a um dos campos assistemáticos do conhecimento tem êsse poder. Pode ascultar as mudanças que se operam no mundo e pela imaginação de seus grandes nomes, definir ao homem comum, novos caminhos.

Se não conseguir formulá-los com nitidez, pelo menos servirá como testemunho de uma época. A época que produz Camus, Kafka e Faulkner (5), já escolheu seu destino: êles testemunham por ela.

$\mathrm{Na}$ época moderna à literatura cabe um papel integrador. O papel de superar o abismo existente entre a arte e a vida, arte e ciência, na medida em que ela mesma é concebida como uma forma de conhecimento dessa totalidade, que é o homem.

Cabe ao escritor viver plenamente sua época, pois só atinge a grandeza, aquêle que sentiu seu próprio tempo. Êste é o segrêdo da universalidade de um Goethe, Balzac ou Cervantes.

Nessa tentativa de traçar com lucidez os quadros do mundo, onde se desenrola o drama humano, num período de transição, é que a literatura deixará de ser o "sorriso da sociedade",

(5). - Em Faulkner o diálogo não é uma relação entre duas consciências, é uma relação com vistas à ação. Ele não exclui inteiramente o monólogo, como por exemplo em "Tandis que j'agonise". Nota Claude Edmonde Magny, que "chez Faulkner l'analyse intérieure alterne perpetuellement avec l'énoncé des comportements" in L'Age du roman americain, pág. 50. Paris, 1948. No entanto, sua obra, como a de Hemingway, Dos Passos e Caudwel estrutura-se sob modelos behatvoristas inspirados na técntca $d_{0}$ cinema norteamericano. A respeito das influências do cinema no romance americano e francês após-guerra, veja-se as pertinentes observaçōes de Magny, ob. cit., pág. 11. 
para ser o testemunho de uma época, uma mensagem acessivel a todos, que permita ao homem independente de sua especialidade sentır-se junto ao seu semelhante, como "igual entre iguais", cumprindo um sábio preceito chinês.

Se as profissões diferenciam o homem, cabe à arte uní-lo em tôrno de ideais comuns. Isso ela pode fazê-lo, pois sua linguagem é universal e a condição humana idêntica em tôda a face dì terra. 